\title{
BANKING REGULATION TODAY: A BANKER'S VIEW
}

\author{
Archir K. DAvis*
}

Bank regulation in this country dates back more than a century and a quarter. It came into being as soon as there was general realization that a bank failure could be more destructive to individuals and to a community than the failure of any other type of enterprise. This is simply because bank liabilities for the most part are held by businesses and individuals and constitute circulating medium. Accordingly, the closing of a bank not only worked hardship on the individual by destroying-or making temporarily unavailable-a portion of his monetary resources, but also, and perhaps more important, a bank failure frequently paralyzed the economic life of the community. On occasion, when failures were numerous, an entire state, or even the nation, was prostrated.

Thus, bank regulation, rudimentary but in a form familiar to us today, first appeared in conjunction with other types of proposals designed to protect individuals and communities against bank failure. Probably the first comprehensive bank regulatory system was included with the first deposit insurance plan, adopted by the State of New York in I829. Certainly regulation was present in the "free banking" acts which first appeared in $1837-1838$ in Michigan and New York and soon spread across the country. These acts were designed not only to facilitate entry into banking but also, and perhaps more important, to protect against the consequences of bank failure by requiring the pledging of collateral against circulating notes issued by banks. Thus, bank regulation appeared in this country approximately a quarter-century before the insurance industry came under government's watchful guidance and more than forty years before states began to regulate public utilities. ${ }^{1}$

Regulation of banks spread throughout the states during the decades following the $x 8_{3}$ os and was generally prevalent by the turn of the century However, in a few instances states did not begin seriously to regulate banks until the early years of the present century. During this time, the federal government also entered the bank regulatory field. First, as a natural consequence of providing for federal chartering of commercial banks in 1863 , federal regulation of banking was provided for national banks. Following the panic of 1907 and the establishment of the Federal Reserve System in I913, federal supervision was extended to those state banks which

* A.B. I932, University of North Carolina; Stonier Graduate School of Banking, I940. President, Amercian Bankers Association, 1966. Chairman, Board of Directors, Wachovia Bank and Trust Company, since 1956. President of the Research Triangle Foundation of North Carolina. Former Director and Vice President, U.S. Chamber of Commerce. Member of Board of Trustees of University of North Carolina, Salem Academy and Salem College, and Converse College.

${ }^{1}$ See Munn v. Illinois, 94 U.S. Ir3 (I877). For information on the origins and extensiveness of early bank regulation, see Champion, Private Enterprise and Public Responsibility in a Free Economy, Nat's Indostriat Conference BoArd Record, June 1966, at 18; 1953 FDIC ANn. Rep. 59. 
chose to enter the Federal Reserve System. Indeed, one of the goals of the formulators of the Federal Reserve Act-as stated in the preamble of that act-was "to establish a more effective supervision of banking in the United States." Despite early expectations that the new system would eventually embrace all banks, large numbers of state banks remained outside of the Federal Reserve System. However, following the dramatic banking collapse of the early I930s, the Federal Deposit Insurance Corporation was created and given regulatory power over all state banks participating in deposit insurance but not members of the Federal Reserve System.

Today commercial bank regulation involves fifty separate state agencies and three federal banking agencies. Perhaps the most striking fact-particularly when compared with bank supervision prior to 1935-is that virtually all commercial banks are subject to some degree of federal regulation, even though every state also exercises regulatory authority over the banks it charters. The only commercial banks not subject to federal supervision are those relatively few banks-numbering only 22I at the end of 1965 -which have state charters and are not insured by the FDIC.

\section{The Goais and Nature of Bank Regulatton}

Basically, bank regulation can be said to have a single goal: the prevention of bank failure. However, because of the extensive and detailed nature of bank supervision, regulation takes on more than this essentially negative function and seeks in addition to guide the banking industry into paths which will provide the public with necessary services. But bank safety still remains the primary and overriding goal.

In this connection it should be noted that bank regulation differs fundamentally from that accorded public utilities and most other regulated industries. There the primary concern is abuse of monopoly or near-monopoly situations, so that price is strictly regulated. In commercial banking-with almost 14,000 separate institutions-regulation is rarely concerned with monopoly or price but is concerned rather with soundness and operations. Indeed, there have been occasions when the major problem of bank regulators was to reduce competition in the interests of protecting the public against the consequences of failure. Whether this particular aspect of bank regulation has been carried too far is a point taken up later.

Basically, regulatory agencies-both state and federal-attempt to maintain safe and sound banking practices through the establishment of regulations and by examination. Regulations permit a range within which banker judgment may be exercised, while establishing bounds beyond which practice has suggested that it might be imprudent to go. The limitation on the amount a bank may lend unsecured to one borrower is akin to the old maxim, "You shouldn't put all your eggs in one basket." Most other regulations are equally sensible although they may involve a higher degree of specialized application to banking practices.

\footnotetext{
${ }^{2}$ Ch. 6,38 Stat. 25 (I913).
} 
A basic characteristic of supervision is close observation by bank examiners of the management practices of individual bankers. It is possible to follow the rules exactly and yet to overlook some things that appear potentially dangerous to a man of broader experience. This is the most important part of bank surveillance because the primary task of an examiner is to determine the net sound capital of each institution. Thus the examiner is required to value each bank asset and, in a real sense, sits in judgment on management decisions on loans and investments.

Another vital aspect of bank regulation involves the structure of banking markets, primarily as affected by new chartering and branching. In the I830s, "free banking" was intended to permit unrestricted entry into banking so long as the organizers met certain statutory standards. This was an understandable reaction to banking by special legislative charter, which frequently depended upon political favoritism, if not worse. However, the states gradually moved away from unrestricted entry and adopted various types of control over chartering in an effort to guard against excessive competition or so-called "overbanking." Additional controls over bank chartering were later adopted by federal agencies. Today entry into banking is regulated at two levels-first, through the chartering authority of the states or of the Office of the Comptroller of the Currency and, second, through the granting of insurance in the case of state banks. The same is true in the case of branching (where permitted by state law) since after state-chartered banks receive the necessary approval from their state supervisory authorities, those which are members of the Federal Reserve System must obtain approval from the Federal Reserve, while state nonmember banks must obtain approval from the Federal Deposit Insurance Corporation.

Bank regulation also extends to other significant areas of banking structure. For example, the bank merger law of $1966^{3}$ appeared to give substantial authority over bank mergers to the three federal banking agencies; the extent to which this authority is finally centered in the banking agencies has just recently been tested in the courts, however, with the result that agency authority is of a preliminary character only. ${ }^{4}$ Also it might be noted that bank holding companies are regulated by the federal government, in this case by a single agency, the Board of Governors of the Federal Reserve System. ${ }^{5}$

If the goal of bank regulation is to prevent bank failure, it may be asked how this ties in with the fact that the federal government also provides deposit insurance to guard against the consequences of bank failure. Putting it another way, is bank regulation really necessary so long as the federal government, through the FDIC, is prepared to protect the public from failures? For example, it has been suggested that the regulatory authorities should not strive too diligently to prevent bank failures. Representative Patman remarked at the dedication of the Federal Deposit

\footnotetext{
${ }^{3}$ I2 U.S.C.A. $\$ 1828$ (c) (Supp. rg66).

'United States v. First City Nat'l Bank of Houston, 87 Sup. Ct. Io88 (I967).

${ }^{5}$ I2 U.S.C.A. $\$ 18_{42}$ (c) (Supp. I966).
} 
Insurance Corporation building that there were not enough bank failures. ${ }^{.}$His feeling stems from the belief that banking markets are not sufficiently competitive and that, if they were more competitive, bank customers would benefit: "When we boast of no bank failures, let's remember that several thousand other business firms may have failed because the banks did not take as many reasonable risks as they might have taken."

There is no question that deposit insurance helps prevent fundamentally sound banks from being drawn into a financial whirlpool of the type that occurred during the depression of the nineteen thirties. Many banks with sound assets were forced into difficulty by sudden and massive deposit withdrawals. If there had been time for things to work themselves out many banks would not have been forced to shut their doors, but there never was enough time for many. Financial panics of the type which marred American history until I933 have not occurred since the deposit insurance legislation was enacted.

While deposit insurance will protect small depositors, larger depositors are not protected by federal insurance. ${ }^{8}$ In addition, the loss of convenience and service rendered by each banking office in the event of failure would be considerable even if deposits were not lost. Long established credit relationships would be brought abruptly to a halt, possibly interrupting local production, and depositors would be inconvenienced by the need to secure new banking services. Therefore, the emphasis in regulation today is no less on maintenance of individual banks in sound condition than it ever was.

Since 1933 - that is, during the past 33 years-there have been a total of 594 bank failures. This number may be contrasted with an average of 500 to 600 bank failures per year during the prosperous years of the 1920s, and more than 9,000 bank failures during the great depression of the early r930s. Probably we will never know to what extent this remarkable record since 1933 can be attributed to improved bank regulation and to what extent it can be attributed to deposit insurance. Undoubtedly each deserves a substantial share of the credit.

\section{II}

\section{State and Federal Regulation}

The dual banking system in the United States is unique in the civilized world. Most simply, it means that a commercial bank may be chartered by either state or federal authorities and thenceforth be supervised by the chartering authority. As we have seen, in the case of state banks supervision is applied by both state and federal authorities. But state law and state regulation are nevertheless the dominant

\footnotetext{
${ }^{6}$ N.Y. Times, June $x_{7},{ }^{1963}$, at 35 , col. 3 .

IId.

${ }^{8}$ Larger depositors are fully protected in those situations where the FDIC arranges for the assumption of all deposits of a failing bank by another insured bank, rather than resorting to individual payments up to $\$ 15,000$.
} 
influences over state banks, which comprise the majority of the commercial banks in the country and hold just under half of the total assets in the commercial banking system. Since it is this basic duality which gives to the commercial banking system much of the vigor and adaptability required by a free enterprise society, it is proper to ask how the regulatory systems are operating at both the state and federal levels.

Unfortunately, there are problems in both areas. While some states have supervisory departments which are the equal in quality to the federal agencies, too many other states are failing in this regard. Very roughly, one might estimate that bank regulation is significantly below standard in probably a third of our states. The causes are varied, but most can be traced to the failure of state legislatures and the respective banking communities to recognize the importance of adequate supervision of banks at the state level.

If the only objective of bank regulation is to prevent bank failure, perhaps we need not be concerned about the fact that in many of our states the bank commissioner is a minor official, that banking department personnel are underpaid and relatively untrained, and that supervisory budgets are inadequate. But with bank regulation goes the power to guide and shape the progress of banking. To the extent that the states fail to provide adequate supervision, they also abandon to the federal government the right to determine the kind of banking which should exist in their state. Fortunately, we find today that the states are becoming increasingly aware of the importance of maintaining adequate regulatory bodies and are making significant progress in upgrading their regulatory systems.

At the federal level the difficulties are not inadequate budgets or insufficient personnel but overlapping and conflicting authority. This has become particularly noticeable in recent years. To some extent, given the tripartite arrangement of federal banking regulation, the possibilities for friction will always be present. After all, because of its insurance function the FDIC has some concern for the soundness of all insured banks, whether state-chartered or federally chartered and whether members or nonmembers of the Federal Reserve System. Similarly, the Federal Reserve has an interest in all of its member banks, whether federally or state chartered. Thus, for the federal regulatory system to work well there must be a strong spirit of cooperation and tolerance among the three agencies. This has not been particularly evident within recent years, and perhaps can be corrected to some extent by sharpening up federal statutes to eliminate those areas where the limits of authority are obscure. But in the long run, if we are to avoid centralization of federal control of banking there must be evidenced a much improved degree of cooperation among the three federal banking agencies.

\section{III}

Bank Regulation and the Future

Because banking regulation is so intimately concerned with the welfare of banksin the sense of protecting the public against failure-it plays a crucial role in deter- 
mining how rapidly, and in what direction, banking can progress. This would not be the case if bank regulation resembled the regulation of public utilities, but the intense concentration of bank regulation on operations and safety make it inevitable that it play the role described. Thus a cautious regulator or a restrictive set of statutes can repress innovation and delay change, while an overenthusiastic regulator or statutes loosely drawn may permit change at too rapid a pace. Let us turn, then, to consider just a few of the issues which both regulators and bankers must face together in the years ahead.

\section{A. Competition}

It is clear that full and unfettered competition would not be suitable for the banking industry, and neither state legislatures nor the federal government have moved this position. Nevertheless, the frequent suggestion that more competition is needed should make everyone think once again about the industry and the direction in which it is moving. Are banks providing the fullest possible range of services compatible with prudent lending standards? Is innovation of new services brisk? Are banks providing too many services which greatly increase their risk exposure? Charges and countercharges fly, as they always do, but the answers to these questions will not come from emotional outbursts. We need painstaking study by bankers, by academic economists, and by other interested parties into the facts concerning the market structure of banking. It is encouraging to see that progress is being made in this area and that more work is constantly being initiated. ${ }^{9}$

The American Bankers Association is doing what it can with its limited resources to further the much needed research in this area. Early in Ig66 the Association awarded the National Bureau of Economic Research a grant of \$210,000 spread over three years to underwrite an investigation into the effect of banking market structure on bank performance. Legislation to change banking almost always affects the balance in banking market, and yet we now know very little about such changes and the effect they have on interest rates, credit availability, loan repayments and other vital matters of public concern. The National Bureau will not answer all our questions, but it will open the door that leads to answers wider than it has ever been opened before.

\section{B. Nonbank Financial Institutions}

The growth of nonbank financial institutions has been remarkably rapid, particularly in the years since the end of the Second World War. Savings and loan associations moved from an industry with $\$ 8.7$ billion assets in 1945 to $\$ 129.4$ billion assets at the end of 1965 . Credit unions which had $\$ 400$ million in assets at the end of the Second World War had \$ro.6 billion in assets at the close of 1965 . Similarly, the

\footnotetext{
${ }^{8}$ For an overview of the highly complex literature on this subject, see Edwards, The Banking Competition Controversy, 3 Nat'L Banking Rev. I (1965), reprinted in U.S. Treasury Dep'T, Studies in Banking Competition and the Banking Structure 303 (r966).
} 
mutual fund industry came into its own in the postwar years while small-loan companies and various private credit arrangements by retails stores all grew rapidly.

Many nonbank financial institutions-such as savings and loan associations and credit unions-have specialized lending functions and have been given supervision specially tailored to their particular requirements. But as they have grown they inevitably tend to move into areas historically reserved for commercial banks. Perhaps this is natural, but it does pose questions of the extent to which the relatively strict standards of bank regulation should be extended to nonbank institutions or, contrariwise, whether somewhat easier standards should be applied to commercial banks. In any event, some adjustment will have to be made if commercial banks and nonbank financial institutions become more and more competitive in the same markets.

One thing that must be borne in mind by the regulatory authorities, however, is that more regulations pertaining to banks will not deal with instabilities that are not part of the commercial banking system. True, banks hold the demand deposits, and they are the bookkeepers for the transactions. But if other types of financial intermediaries are successful, for example, in raising the income velocity of money in a destabilizing way, the answer is not to add more controls to commercial banks just because their depositors use demand deposits more intensively.

\section{Limited Entry}

One of the areas of bank regulation currently under the most intense scrutiny is the ease of difficulty of new entry into the business in various states. The object is to achieve a degree of workable competition ${ }^{10}$ which will help to insure the greatest efficiency possible in the banking industry without generating so much competition that the existence of any one competitor is threatened. Banks across the country have shown great interest in opening new offices where they are permitted, and in unit-banking states there has been a good deal of interest in the chartering of new banks. The Comptroller of the Currency has been particularly receptive in recent years to charter applications from certain areas, and economists from his office have published articles in the National Banking Review which tend to indicate that greater competition has brought decided benefits. ${ }^{11}$ The spectrum of studies existing

\footnotetext{
${ }^{10}$ The expression "workable competition" was introduced by J. M. Clark in his well-known article, Toward a Concept of Workable Competition, 30 AM. Econ. REv. 24I (I940). Clark expresses workable competition in terms of specific conditions which per se establish competition. Jesse W. Markham has subsequently suggested that workable competition need not be defined in terms of arbitrary conditions but in terms of industry performance, regardless of the nature of the industry. See Markham, An Alternative Approach to the Concept of Workable Competition, 40 AM. Econ. REv. 349 (I950). Thus, the concept of workable competition is not a rigid one, although the terminology is frequently used and most economists would come reasonably close to agreeing on the factors that delineate it. The performance criterion is now accepted much more widely than the structure criterion by economists, but the courts secm willing to approach problems in structural terms.

${ }^{11}$ Horvitz \& Shull, The Impact of Branch Banking on Bank Performance, 2 NaT'i Banking Rev. I43 (I964); Motter, Bank Formation and the Public Interest, id. at 299 (1965); Motter \& Carson, Bank Entry and the Public Interest: A Case Study, I id. at 469 (I964); Shull \& Horvitz, Branch Banking and the
} 
on bank entry, however, are not as unequivocal concerning the benefits of less restricted entry as the articles in the Comptroller's Review would suggest. ${ }^{12}$ There have been some situations where regulatory agencies have been very reluctant to permit new entry-perhaps because they knew more about the local situation than was obvious from the outside. But on the whole, there is little reason to believe that policies on chartering or entry into banking markets through branching have been unduly restrictive in the postwar period.

One measure of the volume of banking services available in an area is the number of persons per office. Where branching is prevalent, the number of persons per office declined by about $85^{\circ}$ persons between 1960 and 1964 , and the number of persons per office declined by 434 in states where unit banking is prevalent. ${ }^{13}$ The average population per banking office for all fifty states was 6,469 on December 3r, 1964, about 700 persons per office fewer than the average four years earlier.

\section{Bank Services}

Unlike the regulated utilities, the banking industry is seldom required to provide or maintain a specific service other than to remain solvent and to accept deposits. More often than not, bank regulators are concerned about banks providing too much service, which may raise a bank's expenses too rapidly for safety or greatly expand its risk exposure. Most bank regulations, in fact, specify services which banks may not provide rather than those that banks may provide. For both the regulators and the regulated, it is easy to fall into the ostrich-like pose of never doing anything for the first time. This is the attitude that killed other industries, and this is the attitude that can kill banking. Regulation is guidance, not restriction, and it must be understood that way by legislators as well as by bankers and the regulatory agencies.

In the next five years banks will provide services they do not now provide. The appropriate criterion for judging the aptness of new services is whether or not the addition introduces prudent risks appropriate to a key element of the financial system. Every change in procedure changes the risk structure of the industry. Only when

Structure of Competition, id. at $30 \mathrm{I}$ ( 1963 ), all reprinted in U.S. Treasurx Dep'T, Studies IN Bankino Competition and the Banking Structure (Ig66).

12 Theodore G. Flechis, Banking Market Structure and Performance in Metropolitan Areas: A Statistical Study of Factors Affecting Rates on Bank Loans (ig65); New York State Bankino Dep't, Brance Banking, Bank Mergers and the Public Interest (I964).

${ }^{18}$ I964 FDIC ANN. REp. 144. The FDIC definition of banking offices differs from the Federal Reserve definition in certian respects, the principal one being FDIC inclusion of nondeposit trust company offices. The decline in persons per banking office where state-wide branching was practiced was 898 ; the decline in states with limited-area branching was $82 \mathrm{I}$. The only state in the nation where the persons-per-banking-office ratio rose was Nebraska, and that increase (2 persons) was insignificant. The ratio of persons per banking office is heavily influenced by the extent to which a state's population lives in urban areas where close physical proximity to an office is possible despite a very high ratio of persons per office. Predominantly rural states likes the Dakotas have very low ratios of persons per banking office because of the great geographical dispersion of the population. 
changes contain the potential for unusually large risk should they be proscribed. The only thing a bank has to sell is service, and the service provided must change with shifting demands. As Karl Bopp, the President of the Federal Reserve Bank of Philadelphia, recently remarked concerning the growth of our nation and its financial institutions:

To meet our growing financial requirements, the following alternatives were possible:

I. Existing financial institutions could expand their operations to encompass new needs, or

2. Additional institutions could be established as financial demands evolved.

In fact, existing institutions were either reluctant to meet or unable to satisfy

fully our dynamic demand for financial services. As a result, new institutions were established as new needs became more evident. ${ }^{14}$

At times a struggle develops between banks and the regulators concerning appropriate activities for the banks to undertake, and this is understandable. Such struggles can be kept to a minimum, however, by advance planning. How often do bankers sit down with regulators to discuss where the banking industry is headed and what changes in regulations might be appropriate to foster development along the indicated lines? Probably not often enough.

\section{Summary AND CONCLUSTONS}

The regulation of banking is the oldest and in many ways the most comprehensive regulation of private business to be found in the United States. Its unique characteristics derive from the fact that banks serve not only as a repository of the major portion of the nation's circulating medium but also as the mechanism through which money is created or extinguished by the central bank. At the same time, since banks also serve as the major supplier of credit to individuals and businesses, large and small, it is essential that a workable, nondestructive degree of competition be maintained within the banking system.

Bank regulation-like banking itself-is in the process of change. It has achieved its basic objective-to help guard the public against bank failures-as the record for the past third of a century illustrates. In the future the major problem will be to assure that regulation neither holds back nor overstimulates the necessary growth of banking to meet the everchanging requirements of a dynamic economic system. At the same time, regulation at both the state and federal level must be of such excellence that the dual system of banking is continued and strengthened.

\footnotetext{
14 Bopp, Financial Institutions in a Changing Environment, Federal Reserve Bank of Philadelphis Bos. ReV., June 1966, at 3.
} 